\title{
Effect of Emulsified Diesel Fuel on Performance and Emissions Characteristics
}

\author{
Cyizere Confidence*, Eng Hiram Ndiritu, Benson Gathitu \\ Department of Mechanical Engineering, Pan African University Institute for Basic Sciences, Technology and Innovation, \\ Nairobi, Kenya \\ Email: *cyizereconfidence@yahoo.fr
}

How to cite this paper: Confidence, C. Ndiritu, E.H. and Gathitu, B. (2019) Effect of Emulsified Diesel Fuel on Performance and Emissions Characteristics. Energy and Power Engineering, 11, 333-341. https://doi.org/10.4236/epe.2019.119021

Received: June 28, 2019

Accepted: September 13, 2019

Published: September 16, 2019

Copyright (c) 2019 by author(s) and Scientific Research Publishing Inc. This work is licensed under the Creative Commons Attribution International License (CC BY 4.0).

http://creativecommons.org/licenses/by/4.0/

(c) (i) Open Access

\begin{abstract}
Diesel fuel has been known as the most effective fuel but it is known as a fuel which produces harmful emissions. Later, emulsified diesel fuel was introduced as a better solution but there is no sufficient research data concerning combustion of emulsified fuel. The present work carried out a simulation of non-surfactant emulsified diesel fuel where composition of water in emulsion varied from $0 \%$ to $20 \%$ to determine the ratio of water to diesel which is more effective in reducing the exhaust emissions especially $\mathrm{NO}_{\mathrm{x}}$. For this simulation, $5 \%$ of water in diesel without surfactant was able to reduce $\mathrm{NO}_{\mathrm{x}}$ up to $35 \%$. It was shown that as the percentage of water increases, the power from that fuel combustion reduces.
\end{abstract}

\section{Keywords}

Emulsified Diesel Fuel, Surfactant, Water Content, Diesel Fuel, Micro-Explosion, Emissions, Power

\section{Introduction}

Diesel fuel is the most useful fuel in different fields like heavy industry, transport and agriculture because of its effectiveness but also it has harmful emissions, which is the reason why the researchers have tried to solve this problem using emulsified diesel fuel. Emulsified diesel fuel is the mixture of water and diesel fuel with or without surfactant. The surfactant in the mixture is for stabilizing the mixture [1].

The emulsion without surfactant has to be used just after its production and it was found that the emulsion without surfactant is more effective since the surfactant makes it more expensive than pure diesel fuel [2]. They analyzed the stability of water Diesel emulsion and found that span 80 and tween 80 give the 
most stable emulsion and the percentage varies from $0 \%$ to $10 \%$. When the percentage is beyond $10 \%$, the property of emulsion gets lowered [3]. Nadeem at al 2006 said that using 15\% of water and surfactant, the emulsion was stable and effective [4]. But Patil et al. 2015 said that the percentage of water must be less than $10 \%$ in order to keep the stability of emulsion [3]. After analyzing the effect of water percentage, they said that for emulsion which doesn't contain surfactant, $6.5 \%$ of water give effective water and diesel emulsion [5].

During analysis of stability of emulsified diesel fuel, they tested different emulsifiers like span 20, span 60, span 80, span 85, tween 20, tween 60 and tween only span 80 and tween 80 was stable while other emulsifiers were partially soluble. It was found that as the quantity of water increases, it reduces the stability of emulsion. So, span 80 and tween 80 are the best surfactants and when the percentage of water is beyond $10 \%$, the properties get lowered [3]. Before starting this study NP9, was tried and it was found that NP9 can mix with water but when that mixture is mixed with water; there is formation of small solid particles. Figure 1 shows the physical structure of water in emulsion (a) and diesel in water emulsion (b) [1].

Since water and diesel have different boiling temperature there is process which called micro explosion a process during combustion of emulsified diesel fuel [1].

Apart from reducing the emission, it has been shown that emulsified diesel fuel during combustion produce micro-explosion process which contribute in

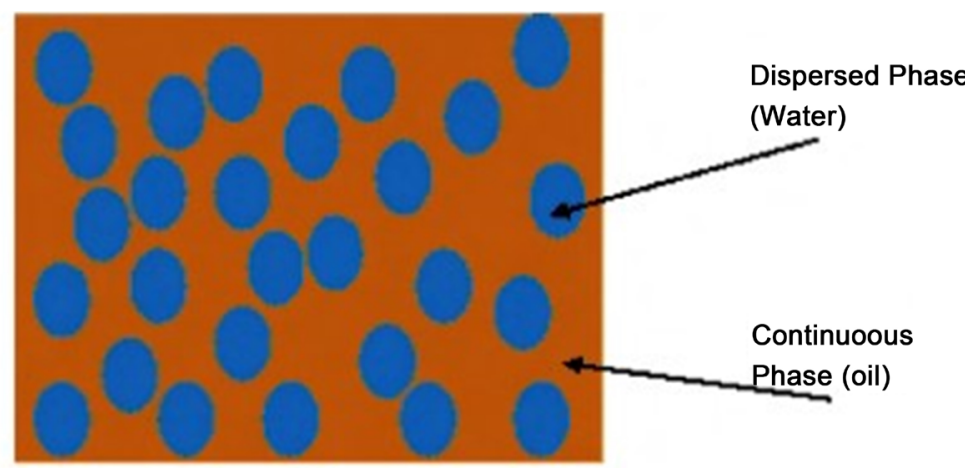

(a)

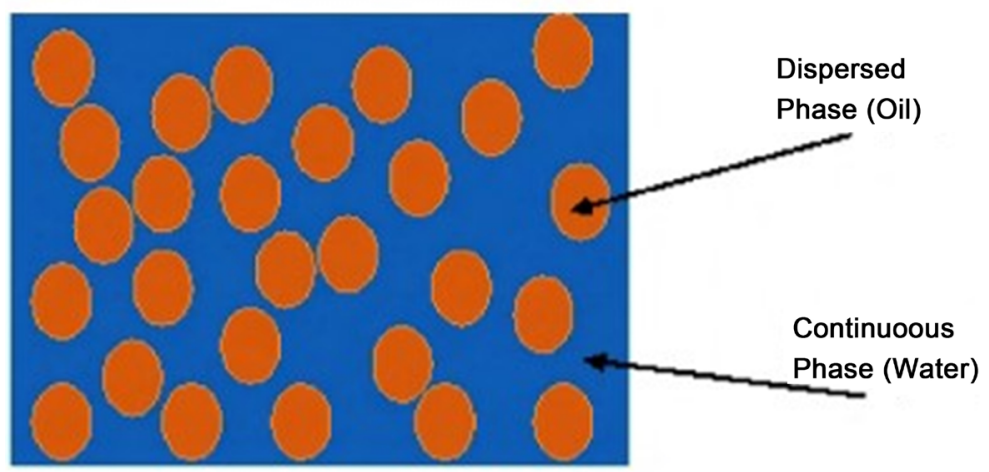

(b)

Figure 1. Physical structure of (a). Water in diesel; (b) Diesel in water. 
atomization and then results to better fuel-air mixture and low fuel consumption [2] [6]. Kumar 2015, after analyzing the effect of emulsion diesel fuel on performance and emissions experimentally the investigator reported that as the water content increases in diesel fuel to make emulsified diesel fuel, it reduces the calorific value of the fuel and it increases the fuel consumption because of water in emulsified diesel fuel; this reduces the brake power. The quantity of water displaces the same quantity of diesel fuel. During combustion the evaporation of water droplets absorb heat instead of releasing heat mean that its reaction is endothermic, water doesn't have calorific value [7]. Using emulsified diesel fuel, it has been shown by Nadeem et al. that there is a small reduction in power comparing to the neat diesel. This is because heat value is reduced by additional water which will absorb heat during evaporation and that increase fuel consumption [4]. But emulsified diesel fuel has been shown as better performance comparatively because of reduction of emissions [2] [7].

Regarding $\mathrm{NO}_{\mathrm{x}}$ obtained after reaction of oxygen and nitrogen. Nitrogen ion which is very reactive is formed at high temperature and pressure in the combustion chamber. The researchers found that after using emulsified diesel fuel the excess oxygen react with $\mathrm{OH}$ ion from water instead of reacting with nitrogen ion. Monoatomic nitrogen atom has high ionization level which makes it to produce different nitrogen oxides like $\mathrm{NO}, \mathrm{NO}_{2}$ [2]. And also, water in Fuel absorbs the latent heat of vaporization which results in the reduction of peak temperature in the combustion chamber and results in the reduction of $\mathrm{NO}_{\mathrm{x}}$ [2]. It has been shown that Soot and $\mathrm{NO}_{\mathrm{x}}$ are dependent on temperature, the soot increases as the temperature is reducing but $\mathrm{NO}_{\mathrm{x}}$ reduces as temperature is reducing. The temperature of emulsified diesel is lower than temperature of diesel fuel which means that the soot from emulsified diesel fuel is higher than soot from diesel fuel [8]. Kumar2015 et al. said that $\mathrm{NO}_{\mathrm{x}}$ is produced at high temperature and emulsified diesel fuel produce lower heat release compare to neat diesel, so the peak temperature is lower which reduces the quantity of $\mathrm{NO}_{\mathrm{x}}$ [7] [4]. Emulsion fuel has long ignition delay (water has to evaporate before ignition) this reduces the cylinder pressure and restricts the $\mathrm{NO}_{\mathrm{x}}$ formation [2]. When ignition temperature is less than $1400 \mathrm{~K}$, there is no oxidation of CO. For emulsified diesel fuel, there is increase in $\mathrm{CO}$ which is produced from the $\mathrm{OH}$ from water which contributes in oxidation of $\mathrm{C}$ to $\mathrm{CO}$. It has been shown that there is no significant change comparing pure fuel and emulsified diesel [2].

This research is being carried out to optimize the emulsified diesel fuel in order to minimize the emission by determining the ratio of water to diesel which is more effective in reducing the exhaust gas emission especially $\mathrm{NO}_{\mathrm{x}}$.

\section{Methodology}

\subsection{Materials}

For this simulation study, water was used at different percentages to form emulsified diesel fuel where the water percentage was varying from $0 \%$ to $20 \%$. So, 
using the list of materials available in ANSYS Fluent, the water content and diesel have been changed to analyze the effect of emulsified diesel fuel.

\subsection{Simulation}

\subsubsection{Domain Configuration}

The geometrical model of combustion chamber is generated using ANSYS fluent R17.1 and the model is $2 \mathrm{D}$. The dimension of the model was chosen because of the capacity of computer and time for simulation. This model is $87.5 \mathrm{~mm}$ of diameter and $10 \mathrm{~mm}$ of length. For meshing, the geometrical model mesh was generated and simulated by ANSYS fluent R17.1. The number of nodes is 681 and the number of elements is 594 and the mesh is in quadrilateral form as Figure 2 shows. The geometrical model in $2 \mathrm{D}$ is representing the combustion chamber in cylinder form.

The solver type was pressure-based because flow was incompressible and subsonic, the time was considered to be steady and gravitational acceleration in $\mathrm{Y}$-axis direction was $-9.81 \mathrm{~m} / \mathrm{s}^{2}$. Energy was activated to solve energy in model, for viscous model, K-epsilon was activated to solve turbulence.

Discrete phase model was $\mathrm{ON}$ to model the spray of fuel where the fuel was pure diesel and emulsified diesel fuel with different percentage of water $0 \%$ $20 \%$. And the number of iterations was 500 .

\subsubsection{Governing Equations}

The geometrical model of combustion chamber was generated using ANSYS fluent R17.1.

For this simulation, the governing equations were solved by ANSYS-Fluent software; those governing equations are:

\section{Mass conservation equation}

$$
\left(\nabla \cdot V_{i}\right)=0
$$
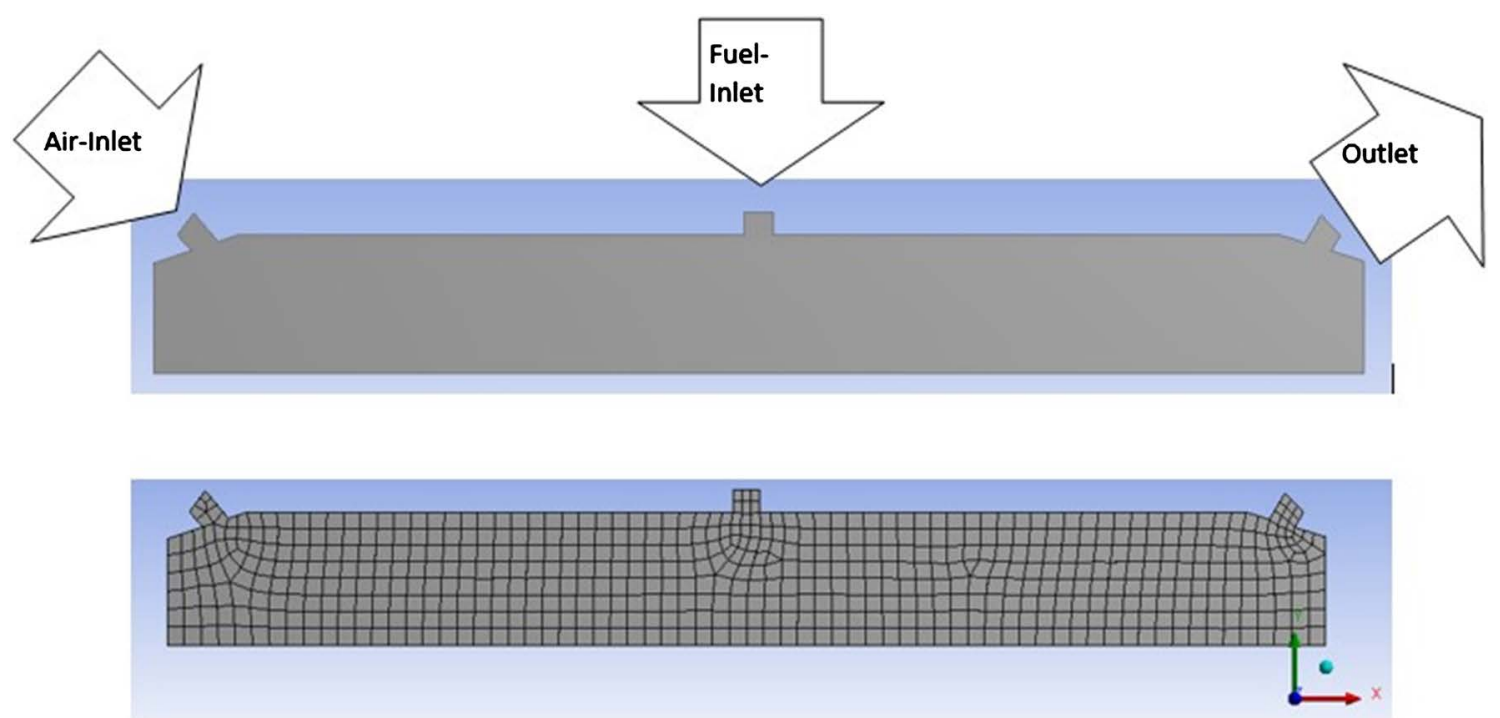

Figure 2. Geometrical model and its meshing. 


\section{Momentum conservation equation}

$$
\rho\left(\nabla \cdot V_{i}\right)=F_{i}-\nabla \cdot P+\mu \nabla^{2} V_{i}
$$

\section{Energy conservation equation}

$$
\left[\nabla\left(\nabla \cdot \rho V_{i}\left(C_{p} T\right)\right)-\frac{\lambda}{C_{p}} \nabla \cdot\left(C_{p} T_{i}\right)\right]=-\dot{H}
$$

\section{Species conservation equation}

$$
\nabla \cdot\left(\rho V_{i}\right)=(\rho D \nabla \cdot Y)-\omega
$$

where the operator $\nabla$ in cylindrical coordinate $\operatorname{system}(r, \theta, z)$ is given by

$$
\nabla=\frac{1}{r} \frac{\partial}{\partial r} r+\frac{1}{r} \frac{\mathrm{d}}{\mathrm{d} \theta}+\frac{\mathrm{d}}{\mathrm{d} z}
$$

where $\rho$ is density; $V_{i}$ is velocity vector; $\mu$ is dynamic viscosity; $P$ is static pressure; $F_{i}$ is Body force; $T=$ Temperature; $T_{f}=$ Flame temperature; $T_{o}=\mathrm{Am}$ bient temperature, $T_{S}=$ Surface temperature; $\omega=$ Rate of consumption of species; $D=$ Species mass diffusion coefficient; $Y=$ species mass fraction; $\dot{H}=$ Heat input; $C_{p}=$ Specific heat capacity; $\lambda=$ Heat conductivity $\partial=$ Partial differential operator; $i=(r, z)$ are cylindrical coordinates.

The above governing equations were solved by pressure-based solver because the flow is incompressible and subsonic and it was solved by using ANSYS Fluent 17.1 to generate the unknown parameters like temperature, pressure, $\mathrm{CO}_{2}$ emission $\mathrm{NO}_{\mathrm{x}}$ emission and soot emission [9]. Figure 3 shows the simulation

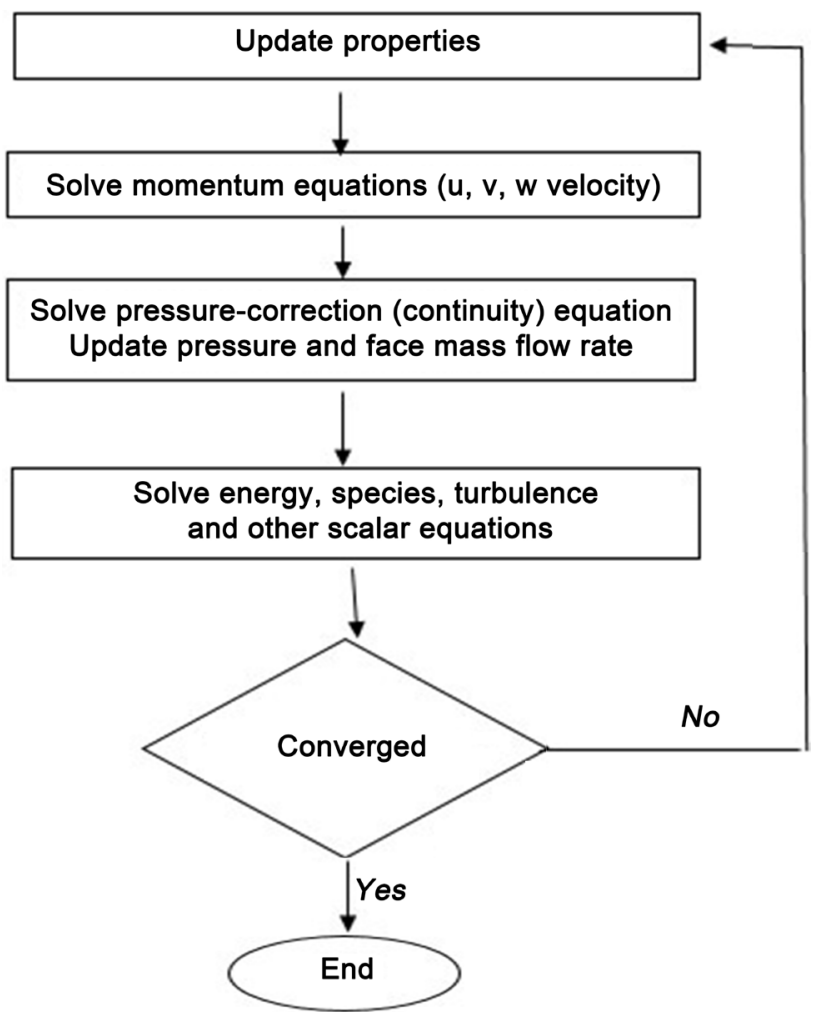

Figure 3. Simulation Flowchart using pressure-based solver. 
flow chart using pressure-based solver.

\section{Results Discussion}

\subsection{Performance Characteristics}

The temperature of the emulsified diesel fuel is lower than the temperature of pure diesel fuel, this is because for emulsified diesel fuel, during the micro explosion process there is absorption of heat to evaporate water droplets in fuel which promote the atomization and then results in better fuel-air mixing and rapid evaporation of diesel fuel. Water in diesel fuel evaporates first because the boiling temperature of water is less than boiling temperature of diesel fuel. And that process of micro explosion also reduces the pressure inside combustion chamber as Figure 4 shows [8].

For power, energy content per volume or mass (energy density) is the energy stored in fuel per unity of volume or per unit of mass. The liquid hydrocarbons are the fuels which store more energy compared to other fuels. The liquid hydrocarbons have $33 \mathrm{MJ} / \mathrm{L}$, alcohol has $29 \mathrm{MJ} / \mathrm{L}$ due to oxygen content and gaseous fuels contain much less energy due to large volume occupied by the gaseous molecules, for example, hydrogen has $12 \mathrm{KJ} / \mathrm{L}$ at standards condition. Hydrogen can be compressed to $2500 \mathrm{~atm}$ to get equivalent energy per volume as hydrocarbons fuels but it very expensive because of storage and safety issues [10]. As the quantity of water in diesel increases, this reduces the power because water doesn't have calorific value and when you are preparing emulsified diesel fuel; quantity of water displaces the same quantity of diesel fuel as Figure 5 shows. So, during evaporation of water droplets, there is absorption of heat which reduces the power [4] [7] [11]. Figure 6 is showing the effect of increasing water percentage on temperature.

\subsection{Emissions Characteristics}

The simulation of emulsion was without surfactant. And it was tested from $0 \%$ $20 \%$ of water and it was found that at $5 \%$ of water, emulsion gave minimum nitrogen

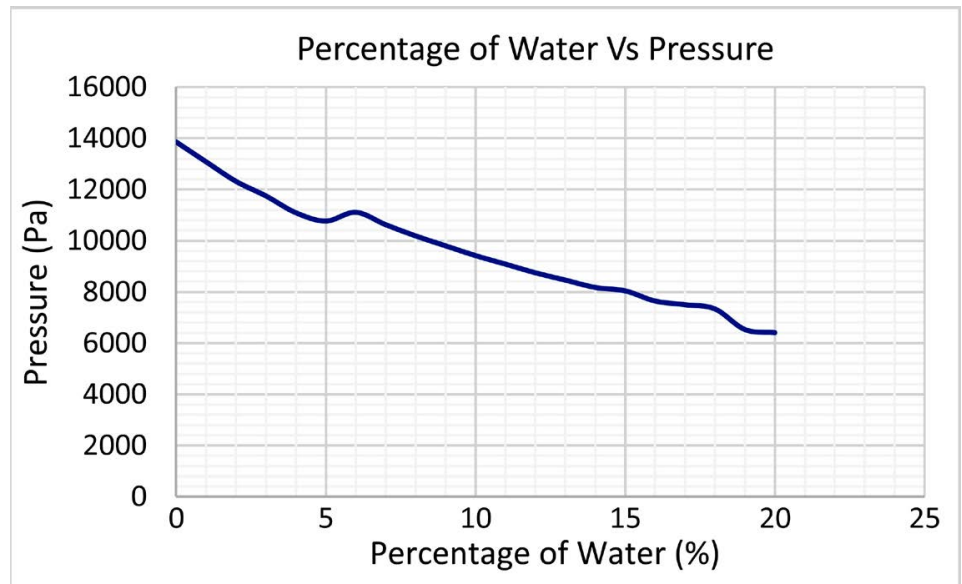

Figure 4. Percentage of water vs pressure. 
oxide emission and it reduced up to 35\% compared to pure diesel fuel. Patil 2015 said that the percentage of water must be less than $10 \%$ to keep the property of emulsion [3]. Ramlan et al. 2016 said that using 6.5\% reduced $\mathrm{NO}_{\mathrm{x}}$ up $23 \%$ and that they used emulsion without surfactant. Figure 7 showed that $\mathrm{NO}_{\mathrm{x}}$ minimized at $5 \%$ and reduced to $35 \%$ [5].

For carbon dioxide emitted from emulsified diesel fuel, there no significant change comparing to the pure diesel but as Ramlan, reported that when carbon dioxide starts to reduce it means that there is production of some carbon monoxide

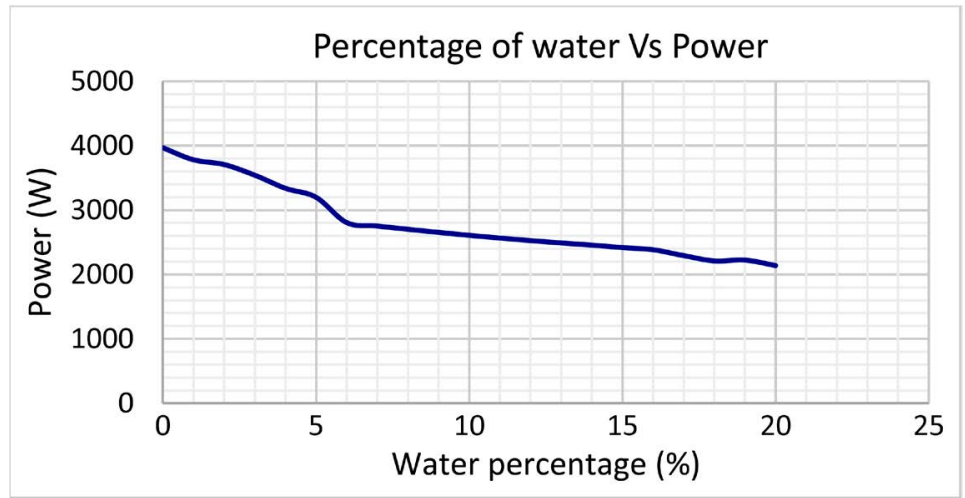

Figure 5. Percentage of water vs power.

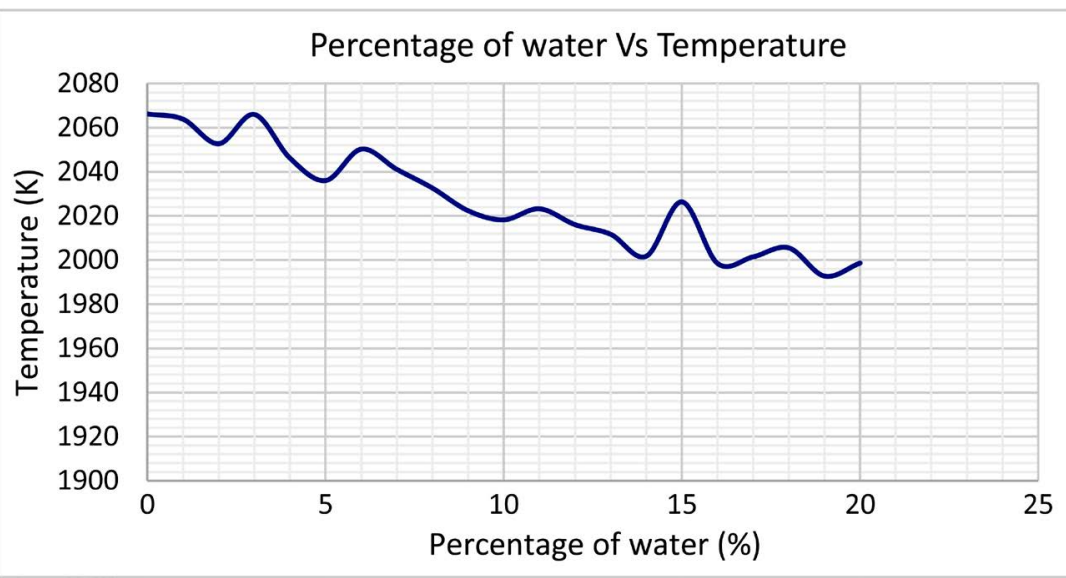

Figure 6. Percentage of water vs temperature.

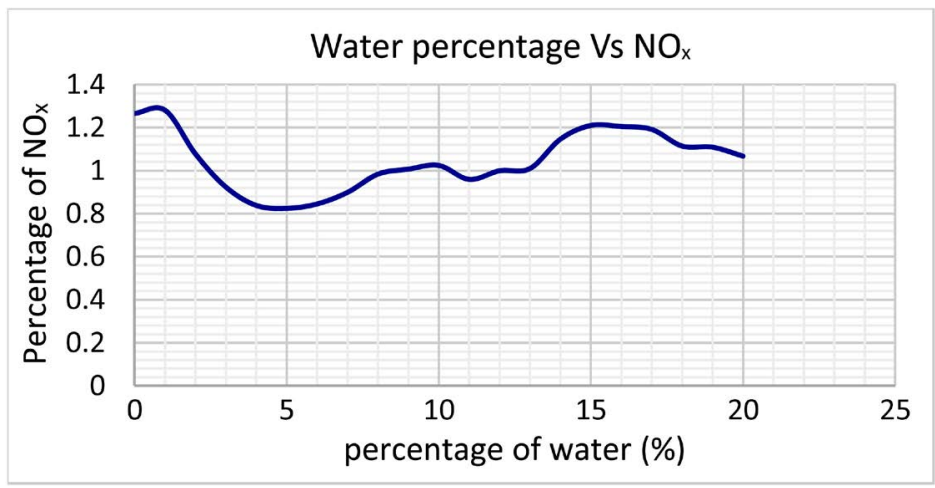

Figure 7. Water percentage vs $\mathrm{NO}_{\mathrm{x}}$. 


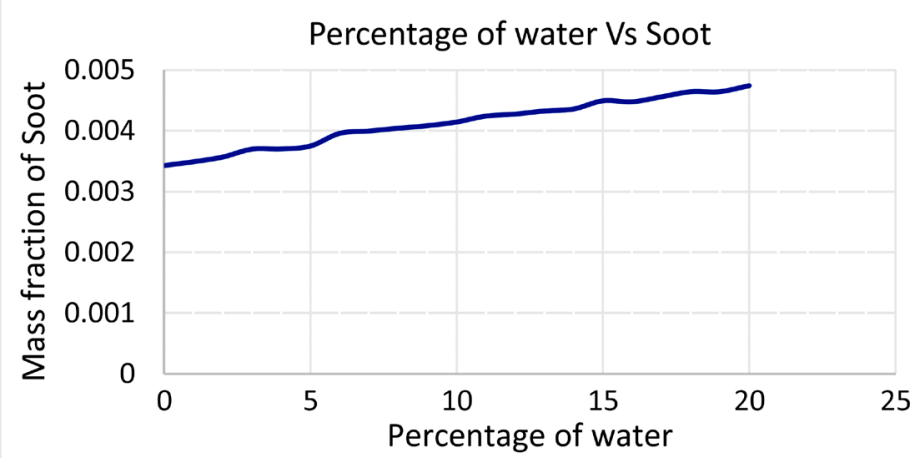

Figure 8. Percentageof water vs soot.

meaning that the reduced carbon dioxide is being converted into carbon monoxide [5]. It has been found that there is no difference on $\mathrm{HCs}, \mathrm{CO}$ and $\mathrm{CO}_{2}$ production by using emulsified diesel fuel or neat diesel fuel [11].

Soot is carbon deposits divided into small particles and they are deposited from flames during incomplete combustion of fuel. Using numerical method, they found that soot increases as the temperature is getting low in combustion chamber and the reduction of temperature is caused by absorption of heat of vaporization process and leads to incomplete combustion. Soni et al. 2015 said that soot and $\mathrm{NO}_{\mathrm{x}}$ are all dependent on temperature and the reduction of temperature and pressure is from better mixing and micro explosion of water droplets by taking evaporation in combustion chamber [8]. Figure 8 is showing the effect of water percentage to the soot.

\section{Conclusions}

After analyzing non-surfactant emulsified diesel fuels by simulation where $\mathrm{NO}_{\mathrm{x}}$ was modeled, soot was modeled at different percentages of water, from $0 \%$ $20 \%$, and the following conclusions may be drawn:

- At $5 \%$ of water in emulsified diesel fuel, $\mathrm{NO}_{\mathrm{x}}$ was minimum; it reduced up to $35 \%$.

- As water content increase, the power from fuel reduce.

- Soot increase as water percentage increase in emulsified diesel fuel.

- There is no significant change in carbon dioxide.

- There is reduction of temperature and pressure as water percentage increase.

\section{Acknowledgements}

The authors would like to acknowledge Pan African University Institute for basic Sciences, Technology and Innovation for funding this research.

\section{Conflicts of Interest}

The authors declare no conflicts of interest regarding the publication of this paper.

\section{References}

[1] Hagos, F.Y., Aziz, A.R.A. and Mohd Tan, I. (2011) Water-in-Diesel Emulsion and Its 
Micro-Explosion Phenomenon-Review. Fluid Dynamics and Thermodynamics Technologies (FDTT) 2011, Bali, Indonesia, 1-3 April 2011, 314-318.

[2] Mazlan, N.A., et al. (2018) Effects of Different Water Percentages in Non-Surfactant Emulsion Fuel on Performance and Exhaust Emissions of a Light-Duty Truck. Journal of Cleaner Production, 179, 559-566. https://doi.org/10.1016/j.jclepro.2018.01.143

[3] Patil, H., Gadhave, A., Mane, S. and Waghmare, J. (2015) Analyzing the Stability of the Water-in-Diesel Fuel Emulsion. Journal of Dispersion Science and Technology, 36, 1221-1227. https://doi.org/10.1080/01932691.2014.962039

[4] Nadeem, M., Rangkuti, C., Anuar, K., Haq, M.R.U., Tan, I.B. and Shah, S.S. (2006) Diesel Engine Performance and Emission Evaluation Using Emulsified Fuels Stabilized by Conventional and Gemini Surfactants. Fuel, 85, 2111-2119. https://doi.org/10.1016/j.fuel.2006.03.013

[5] Atiqah, N., et al. (2016) Performance and Emissions of Light-Duty Diesel Vehicle Fuelled with Non-Surfactant Low Grade Diesel Emulsion Compared with a High Grade Diesel in Malaysia. Energy Conversion and Management, 130, 192-199. https://doi.org/10.1016/j.enconman.2016.10.057

[6] Lif, A. and Holmberg, K. (2006) Water-in-Diesel Emulsions and Related Systems. Advances in Colloid and Interface Science, 126, 231-239. https://doi.org/10.1016/j.cis.2006.05.004

[7] Kumar, P., Senthur, N.S., Premkartikkumar, S.R. and Annamalai, K. (2015) Effect of Emulsified Fuel on Performance and Emission Characteristics in DI Diesel Engine. Journal of Chemical and Pharmaceutical Sciences, 7, 215-218.

[8] Soni, D.K. and Gupta, R. (2015) Comparison of Performance and Emission Characteristics of Diesel and Diesel-Water Blend under Varying Injection Timings. International Journal of Engineering, Science and Technology, 7, 49-59. https://doi.org/10.4314/ijest.v7i4.6

[9] Andsaler, A.R., Khalid, A., Adila, A.N.S., Sapit, A. and Jaat, N. (2017) The Effect of Nozzle Diameter, Injection Pressure and Ambient Temperature on Spray Characteristics in Diesel Engine. Journal of Physics. Conference Series, 822, Article ID: 012039. https://doi.org/10.1088/1742-6596/822/1/012039

[10] McAllister, S., Chen, J.-Y. and Carlos, F.-P.A. (2011) Fundamentals of Combustion Processes. Springer Nature, Switzerland, 177-198.

[11] Barnes, A., Duncan, D., Marshall, J., Psaila, A., Chadderton, J. and Eastlake, A. (2010) Evaluation of Water-blend Fuels in a City Bus and an Assessment of Performance with Emission Control Devices. Technical Papers, 1, No. 724. 